\title{
Universiteit
}

Leiden

The Netherlands

\section{The production and composition of Chinese lead-barium glass through experimental laboratory replication}

Ma, Q.; Braekmans, D.J.G.; Shortland, A.; Pollard, A.M.

\section{Citation}

Ma, Q., Braekmans, D. J. G., Shortland, A., \& Pollard, A. M. (2021). The production and composition of Chinese lead-barium glass through experimental laboratory replication. $J$ Non-Cryst Solids, 551. doi:10.1016/j.jnoncrysol.2020.120409

Version: $\quad$ Publisher's Version

License: $\quad$ Leiden University Non-exclusive license

Downloaded from: https://hdl.handle.net/1887/3263588

Note: To cite this publication please use the final published version (if applicable). 


\title{
The Production and Composition of Chinese Lead-Barium Glass through Experimental Laboratory Replication
}

\author{
Qian Ma*,a, Dennis Braekmans ${ }^{\mathrm{b}}$, Andrew Shortland ${ }^{\mathrm{b}}$, A. Mark Pollard*,a \\ ${ }^{a}$ School of Archaeology, University of Oxford, 1 South Park Road, Oxford, OX1 3TG, UK \\ ${ }^{\mathrm{b}}$ Cranfield Forensic Institute, Cranfield University, Defence Academy of the United Kingdom, Shrivenham, Wilts, SN6 8LA, UK
}

\section{A R T I C L E I N F O}

\section{Keywords:}

Lead-barium glass

Crucibles

Sodium

Opacifier

Chinese glass

\begin{abstract}
A B S T R A C T
Lead-barium glass appeared during the late Warring States period in China (457 - 221 BCE) and was considered as a Chinese invention due to the unique presence of high barium. There is no indication as to how it was made. A set of twenty-four different combinations of possible raw materials were melted to test and systematically evaluate the possible recipes for lead-barium glass. Specifically, the function and source of sodium in leadbarium glass were explored. The results show that sodium source is crucial for lead-barium glass forming in this particular system. This paper explores an alternative formulation since sodium flux is not reported in historical Chinese sources, in which the $\mathrm{Na}_{2} \mathrm{O}$ is provided by including soda-lime glass in the mixture. This particular formulation provides a potential explanation for the source of the sodium in lead-barium glass.
\end{abstract}

\section{Introduction}

The origins of glass bead-making in China have been attributed to an accidental by-product of ceramic glaze manufacture. The Chinese term 'proto-porcelain' (which in the West is referred to as 'stoneware') refers to the low-fired glazed ceramics which appeared from the Shang (1700 - 1027 BCE) to the Zhou (1027 - 221 BCE) dynasties. During the production process, it appears that drops of glaze can flow down from the stoneware during the firing process and subsequently produce a glass drop. According to the analysis of glass drops found in the Henglingshan Tomb Site in Boluo, Guangzhou, dating the Early Spring and Autumn period ( $~ 800-700 \mathrm{BCE}),[1]$ argued that these drops of glaze were the prototype of Chinese glass beads. Given their rarity and value, they could have been used as jewels or ornaments in the swords of nobles. A decorative glass drop on a sword was, for example, excavated from No. 1 Chu Mausoleum (496 - 464 BCE), Hubei Province. PIXE analysis of this particular decorative glass showed that it is a wood ash glass, and the proportion of $\mathrm{K}_{2} \mathrm{O}$ is higher than $\mathrm{Na}_{2} \mathrm{O}$ [2]. Wood ash glass did not appear in Europe until around $800 \mathrm{CE}$ [3]. Abd-Allah [1] noted that there is no published data from contemporary Egyptian and Mediterranean plant ash glasses in which the $\mathrm{K}_{2} \mathrm{O}$ value is higher than the $\mathrm{Na}_{2} \mathrm{O}$ value, which in their view suggested that this decorative glass was produced in China. Therefore, it was concluded that Chinese glass evolved from stoneware glazes made using wood ash.

According to scientific research and historical records, the trade between Mediterranean and China through the Eurasian Steppe can be dated to the $10^{\text {th }}$ century BCE, which was the Late Shang and the Early Zhou Dynasty (1046 - 256 BCE: [4]). Merchants brought marine products such as shells from the eastern coastal region of China to Taklamakan in the Shang Dynasty (1600 - 1046 BCE: [5]). silk was exported from China to Europe in the 4th century BC [6]. Nomadic people conquered some of the areas of Middle Asia through which the Steppe Route passed in the 1st century $\mathrm{BC}$, and the wars that these nomadic people started with neighbouring countries and the robbery of trade caravans almost suspended the commodity circulation between China and Europe [7]. When the Qin Empire (221 - 207 BCE) united China after the Warring States period (475 - $221 \mathrm{BCE})$, it was soon replaced by the Han Empire (202 BCE - $220 \mathrm{CE}$ ) fifteen years later. The social economy and currency economy soon recovered with the implementation of low-taxation policy during the early Han Period and the Han Empire became one of the most powerful countries. Later, Emperor Han Wudi (156 - 87 BCE), the 7th emperor of the Han Dynasty, commanded officer Zhang Qian 张寒 to investigate the old trade route between China, the Middle East and Europe. Zhang Qian started his first journey from the city of Chang'an (modern Xi'an) in 139 BCE. Merchants joined with Zhang Qian for his second investigation in 119 $\mathrm{BCE}$, and they gained huge profits during this trip by exchanging their products with foreigners. The prosperous age of commodity circulation along the Northwest (Desert) Silk Road began then, as Egyptians and Romans began purchasing silk products from the Parthians, which had

\footnotetext{
* Corresponding Authors.

E-mail addresses: qian.ma@sjc.ox.ac.uk (Q. Ma), mark.pollard@arch.ox.ac.uk (A.M. Pollard).
} 
been imported from the Han Empire [7]. Lead-barium glass was invented in China during the Warring States period, probably due to technology exchange with the western world. It has, however, commonly been considered to be a uniquely Chinese-made glass due to its high proportion of barium. This type of glass arose during the Late Warring States period (around the $5^{\text {th }}$ century BCE) and suddenly disappeared after the Han Dynasty ((around the $2^{\text {nd }}$ century CE - [8]). Chinese glassmakers produced glass to simulate other materials, such as hardstones, or as a vehicle for pictorial presentation [9]. A few contemporary documents mention glass, but none of them clearly refer to lead-barium glass. For example, 'Lun Heng Shuai Xing Pian' 论衡 率性 篇, written by Wang Chong 王充 in $87 \mathrm{CE}$, first documents the formulation of glass. He mentioned that Daoists used 'Wu Shi' 五石 (five different components) to produce imitation jade, and that this glass could also be used as the sun flint (magnifying glass) after polishing. 'Wu Shi' included Dan Sha 丹砂 (mercuric sulfide HgS), Xiong Huang 雄 黄 (realgar $\mathrm{As}_{4} \mathrm{~S}_{4}$ ), Bai Fan 白矾 (alum $\mathrm{KAl}\left(\mathrm{SO}_{4}\right)_{2} \cdot 12 \mathrm{H}_{2} \mathrm{O}$ ), Zeng Qing 曾 青 (copper sulfate $\mathrm{CuSO}_{4}$ ) and $\mathrm{Ci}$ Shi 慈石 (magnetite $\mathrm{Fe}_{3} \mathrm{O}_{4}$ ), as the main ingredients for the elixir. Chinese Emperors all sought longevity, and Daoists were required to provide the appropriate elixir. Clearly, these five components cannot produce glass, but the context suggests that there may be some connection between Daoist alchemy and glass production.

The documentation in 'Formula of Tai Qing Elixir' 太清丹经要诀 written by Sun Simiao 孙思邀 in the Late Sui and the Early Tang Dynasty (618 - $907 \mathrm{CE})$ reinforces this hypothesis. He mentioned that the white 'Tai Qing' elixir was made by mixing and firing $100 \mathrm{~g}$ Shui Jing 水精 (silica crystal) powder with $1000 \mathrm{~g}$ lead oxide (PbO), and this could actually be the formula for high lead glass. This book also documents the formula for making 'Jade': '500 g shell $\left(\mathrm{CaCO}_{3}\right)$ is ground into powder and sealed in a bamboo pipe with saltpetre $\left(\mathrm{KNO}_{3}\right)$; then the bamboo pipe is soaked in vinegar (acetic acid: $\mathrm{CH}_{3} \mathrm{COOH}$ ) for twenty days; $500 \mathrm{~g}$ silica quartz powder is poured into the bamboo pipe after twenty days and directly fired with coal. The shell functioned as the stabilizer and saltpetre was the flux. It is clear that the 'jade' in this case was actually a potash glass.

The formula for 'Liu Li' 琉璃 is documented in 'Jin Hua Yu Ye Elixir' 金华玉液大丹 (anonymous) during the Tang Dynasty, which was a mixture of $250 \mathrm{~g}$ lead oxide ( $\mathrm{PbO}), 100 \mathrm{~g}$ saltpetre $\left(\mathrm{KNO}_{3}\right)$ and $100 \mathrm{~g}$ borax $\left(\mathrm{Na}_{2} \mathrm{~B}_{4} \mathrm{O}_{7} \cdot 10 \mathrm{H}_{2} \mathrm{O}\right)$. Lead oxide, saltpetre and borax could all function as fluxes, so this could be the formula for the $\mathrm{PbO}-\mathrm{Na}_{2} \mathrm{O}-\mathrm{K}_{2} \mathrm{O}$ glass during the Tang Dynasty. 'Duo Neng Bi Shi' 多能鄙事 written by Liu Ji 刘基 in the Early Ming Dynasty (1368 - 1644 CE) documents another formula for a type of 'Liu Li': $200 \mathrm{~g}$ metallic lead, $150 \mathrm{~g}$ saltpetre $\left(\mathrm{KNO}_{3}\right), 100 \mathrm{~g}$ alum $\left(\mathrm{KAl}\left(\mathrm{SO}_{4}\right)_{2} \cdot 12 \mathrm{H}_{2} \mathrm{O}\right)$, and $100 \mathrm{~g}$ silica quartz are ground and mixed, then fired with coal. Saltpetre and alum could both be the fluxes, so the 'Liu Li' in this case was a potash lead glass.

In one of the first modern discussions of the chemistry of such glass, Cui et al., [10] summarized five types of Chinese lead-barium glasses. The main difference between these five groups was the total concentrations of $\mathrm{PbO}$ and $\mathrm{BaO}$, although the $\mathrm{PbO} / \mathrm{BaO}$ ratios appear to have been fixed at either $3 / 1$ or $3 / 2$. During the last few decades of research on lead-barium glass, it seems that its chemical composition is more complicated than this, meaning that it can no longer be simply summarized as five types. Although the original classification of Cui et al., [10] has subsequently been shown to be too simplistic, patterns can still be seen in the $\mathrm{PbO} / \mathrm{BaO}$ ratio for the glass excavated from different regions in China. For example, the average $\mathrm{PbO} \%$ and $\mathrm{BaO} \%$ for lead-barium glass excavated from the Shirenzigou Site (Xinjiang) are $49.63 \%$ and $7.64 \%$ [11]. In contrast, $\mathrm{PbO} / \mathrm{BaO}$ ratios for glass unearthed in Dayunshan Site (Zhejiang) are close to 2 [12], whereas the average $\mathrm{PbO} / \mathrm{BaO}$ ratio for lead-barium glass unearthed in Xi'an is also around 6 [13]. Gan [14] collected 534 lead isotopic measurements from ores and compared them with over 250 lead isotopic measurements from glass. The results show that some lead-barium glass with radiogenic lead signature could have been manufactured in Yunnan
Province. PCA analysis for lead-barium glass unearthed from different provinces also indicates that there could be multiple workshops producing lead-barium glass in the past [11]. These examples not only indicate that there was probably more than one workshop producing lead-barium glass, but also that, given the range of variation measured in the $\mathrm{PbO} / \mathrm{BaO}$ ratio, the lead-barium minerals were probably separately added to the glass batch.

From the literature, we have assembled a representative database of the composition of Chinese $\mathrm{Pb}$-Ba glass containing in excess of 400 samples (Supplementary 1), although not all samples report all elements. Taking the median of each major element oxide, we can suggest that a 'typical' example of $\mathrm{Pb}$-Ba glass has the following composition (by weight): $\mathrm{SiO}_{2}=51.39 \%, \mathrm{PbO}=27.25 \%, \mathrm{BaO}=9.02 \%, \mathrm{Na}_{2} \mathrm{O}$ $=2.27 \%, \mathrm{Al}_{2} \mathrm{O}_{3}=3.00 \%, \mathrm{SO}_{3}=2.20 \%, \mathrm{CaO}=1.50 \%, \mathrm{Cl}=1.22 \%$. From the $\mathrm{BaO}-\mathrm{PbO}-\mathrm{SiO}_{2}$ phase diagram [35], the lowest melting point in the system is approximately $700^{\circ} \mathrm{C}$, but for glass of typical Chinese composition the melting point is likely to be in excess of $1000^{\circ} \mathrm{C}$ - by no means unachievable in ancient furnaces, and illustrating the fluxing power of the $\mathrm{PbO}$. Nevertheless, from the analyses, it is clear that $\mathrm{Pb}-\mathrm{Ba}$ glass contains low but significant levels of alkalis (median $\left.\mathrm{Na}_{2} \mathrm{O}=2.27 \%, \mathrm{~K}_{2} \mathrm{O}=0.57 \%\right)$ and alkaline earths $(\mathrm{CaO}=1.24 \%$, $\mathrm{MgO}=0.53 \%)$. It must be acknowledged that there are limitations in the dataset assembled, particularly in terms of measurements of $\mathrm{Na}_{2} \mathrm{O}$, and also because it is not always certain that the reported samples are glass rather than faience. Many of the analyses were achieved by either XRF or PIXE, and hence the $\mathrm{Na}_{2} \mathrm{O} \%$ was either unreported, or may have been underestimated due to the high detection limits of X-ray analytical techniques with respect to light elements (e.g., [24,43]). Only 258 of the 401 analyses assembled contain definite values for $\mathrm{Na}_{2} \mathrm{O}$. However, according to wet chemistry and LA-ICP-AES analyses, some lead-barium glass samples can show over $6 \% \mathrm{Na}_{2} \mathrm{O}$ (e.g., [6,11]). Fig. 1 shows the distribution of $\mathrm{Na}_{2} \mathrm{O}$ in the dataset, indicating that a small proportion of samples do indeed have values greater than $6 \%$. Henderson [18] believes that the contents of $\mathrm{K}_{2} \mathrm{O}$ and $\mathrm{Na}_{2} \mathrm{O}$ are generally negligible in most lead-barium glass, but he classifies those with $\mathrm{Na}_{2} \mathrm{O}$ ranging between $5.29-9.3 \%$ as soda-lead-barium glass.

There is no doubt that $\mathrm{PbO}$ functioned as the main flux in leadbarium glass, but there is evidence that other fluxes, especially $\mathrm{Na}_{2} \mathrm{O}$, also played a role, as discussed above. Hou [19] suggested that the $\mathrm{Na}_{2} \mathrm{O}$ was from a sodium/lime bearing material. Gan [12] believed that

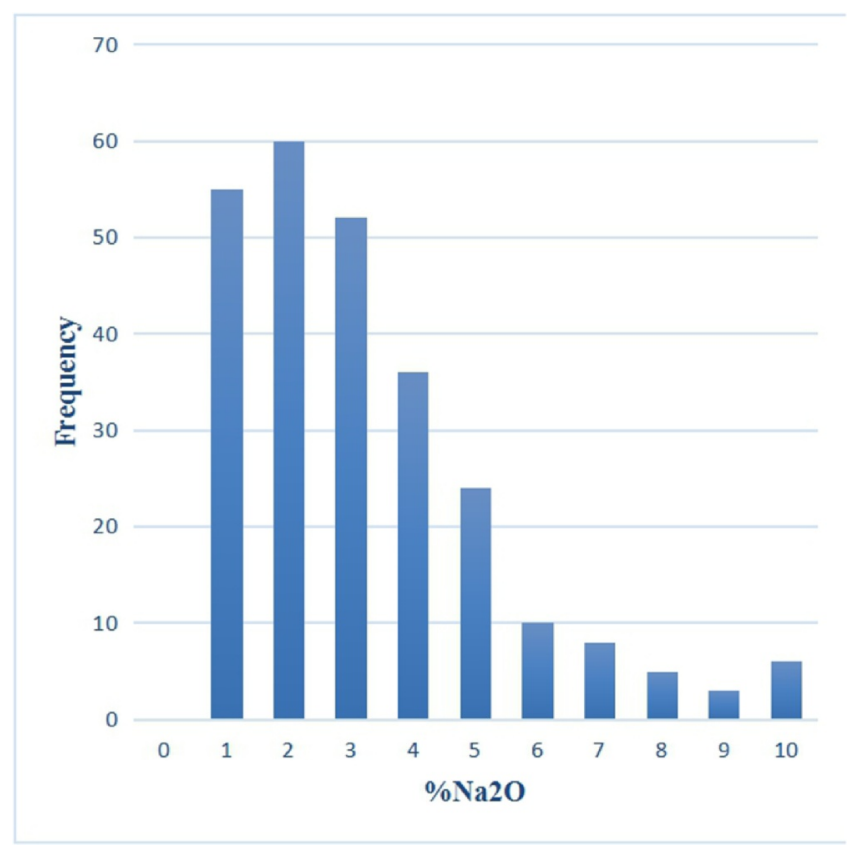

Fig. 1. Distribution of $\% \mathrm{Na}_{2} \mathrm{O}$ in published analyses of $\mathrm{Pb}-\mathrm{Ba}$ glass 
Table 1

The weight $\%$ of the raw materials for 24 crucibles

\begin{tabular}{|c|c|c|c|c|c|c|c|c|c|c|c|}
\hline Weight\% & $\mathrm{SiO}_{2}$ & $\mathrm{BaCO}_{3}$ & $\mathrm{BaSO}_{4}$ & $\mathrm{PbO}$ & $\mathrm{PbS}$ & $\mathrm{CaCO}_{3}$ & $\mathrm{Na}_{2} \mathrm{CO}_{3}$ & $\mathrm{Na}_{2} \mathrm{O} \cdot \mathrm{Al}_{2} \mathrm{O}_{3} \cdot 6 \mathrm{SiO}_{2}$ & $\mathrm{Na}_{2} \mathrm{~B}_{4} \mathrm{O}_{7} \cdot 10 \mathrm{H}_{2} \mathrm{O}$ & $\mathrm{Cu}_{2}(\mathrm{OH})_{2} \mathrm{CO}_{3}$ & soda-lime glass \\
\hline Crucible 1 & 40 & 15 & - & 45 & - & - & - & - & - & - & - \\
\hline Crucible 2 & 40 & - & 15 & - & 45 & - & - & - & - & - & - \\
\hline Crucible 3 & 30 & - & 20 & 50 & - & - & - & - & - & - & - \\
\hline Crucible 4 & 60 & 10 & - & 30 & - & - & - & - & - & - & - \\
\hline Crucible 5 & 35 & 15 & - & 45 & - & - & - & - & - & 5 & - \\
\hline Crucible 6 & - & 10 & - & 40 & - & - & - & - & - & - & 50 \\
\hline Crucible 7 & - & 10 & - & 40 & - & - & - & - & - & 5 & 45 \\
\hline Crucible 8 & - & - & 10 & - & 40 & - & - & - & - & - & 50 \\
\hline Crucible 9 & - & - & 10 & 40 & - & - & - & - & - & - & 50 \\
\hline Crucible 10 & - & 20 & - & 30 & - & - & - & - & - & - & 50 \\
\hline Crucible 11 & - & - & 10 & 30 & - & - & - & - & - & - & 60 \\
\hline Crucible 12 & - & 10 & - & 40 & - & - & - & 50 & - & - & - \\
\hline Crucible 13 & 55 & 15 & - & 25 & - & 2.5 & 2.5 & - & - & - & - \\
\hline Crucible 14 & 57 & 15 & - & 25 & - & 3 & - & - & - & - & - \\
\hline Crucible 15 & 55 & - & 15 & 25 & - & 2.5 & 2.5 & - & - & - & - \\
\hline Crucible 16 & 55 & 15 & - & - & 25 & 2.5 & 2.5 & - & - & - & - \\
\hline Crucible 17 & 33 & 10 & - & 45 & - & 3 & 5 & - & - & 4 & - \\
\hline Crucible 18 & 33 & 10 & - & 50 & - & 3 & - & - & - & 4 & - \\
\hline Crucible 19 & 30 & - & 15 & 45 & - & 2.5 & 4 & - & - & 3.5 & - \\
\hline Crucible 20 & 30 & 10 & - & - & 50 & 2.5 & 4 & - & - & 3.5 & - \\
\hline Crucible 21 & 43 & 15 & - & 25 & - & 2 & 15 & - & - & - & - \\
\hline Crucible 22 & 43 & - & 15 & 25 & - & 2 & 15 & - & - & - & - \\
\hline Crucible 23 & 48 & 20 & - & 30 & - & 2 & - & - & - & - & - \\
\hline Crucible 24 & 30 & 10 & - & 20 & - & 1 & - & - & 39 & - & - \\
\hline
\end{tabular}

the $\mathrm{Na}_{2} \mathrm{O}$ in lead-barium glass was sourced from mirabilite (Glauber's salt: $\mathrm{Na}_{2} \mathrm{SO}_{4} \cdot 10 \mathrm{H}_{2} \mathrm{O}$ ), which is an evaporite mineral sometimes associated with gypsum $\left(\mathrm{CaSO}_{4} \cdot 2 \mathrm{H}_{2} \mathrm{O}\right)$, perhaps also explaining the $\mathrm{CaO}$ content in lead-barium glass. Saltpeter $\left(\mathrm{KNO}_{3}\right)$ was a commonly used flux for potash glass from the $5^{\text {th }}$ century BCE to the $4^{\text {th }}$ century CE in India, Thailand, Vietnam, China, Korea and Japan [20,21,22]. Gan [12] suggested that during the Warring States and the Han dynasty the Chinese could not differentiate between mirabilite and saltpetre, but this seems unlikely. Both Li et al., [23] and Gan [14] have successfully replicated lead-barium glass by mixing and firing $\mathrm{SiO}_{2}, \mathrm{PbO}, \mathrm{BaCO}_{3}$ and sodium feldspar (albite - $\mathrm{Na}_{2} \mathrm{O} \cdot \mathrm{Al}_{2} \mathrm{O}_{3} \cdot 6 \mathrm{SiO}_{2}$ ). They gave no justification for using albite as the source of alkali, but were probably influenced by the use of albite in the bodies of later porcelains [15]. This paper investigates an alternative suggestion, in which the alkali is provided by the use of re-cycled soda-lime-silica glass. The average concentration of $\mathrm{SiO}_{2}$ is significantly lower in lead-barium glass than in soda-lime glass, so our working hypothesis is that lead-barium glass was made from a mixture of soda-lime glass with lead and barium minerals.

Other synthetic barium-containing materials also have a Chinese origin, such as lead-barium faience in the form of Chinese Blue $\left(\mathrm{BaCuSi}_{4} \mathrm{O}_{10}\right)$ and Chinese Purple $\left(\mathrm{BaCuSi}_{2} \mathrm{O}_{6}\right)$, regarded as the Chinese analogues of Egyptian Blue $[14,16]$. These are synthetic pigments invented during the Qin (221-207 BCE) and Han dynasties [17]. Both pigments were used as the blue and purple decoration on the surface of the Terracotta Warriors $[14,11]$. The main difference between leadbarium glass and lead-barium faience is that the glass has higher $\mathrm{Na}_{2} \mathrm{O}$ and $\mathrm{PbO}$, and lower $\mathrm{Al}_{2} \mathrm{O}_{3}, \mathrm{~K}_{2} \mathrm{O}$, and $\mathrm{CaO}$, resulting in the lead-barium faience being less vitrified. According to Gan [14] replication experiment, 1) by mixing and burning $\mathrm{BaO} / \mathrm{BaCO}_{3}, \mathrm{CuO}$ and $\mathrm{SiO}_{2}$ without $\mathrm{PbO}$ as a catalyst, Chinese purple were first generated when the temperature reached over $800^{\circ} \mathrm{C}$; by increasing the temperature with sufficient $\mathrm{SiO}_{2}$, Chinese purple turned into Chinese blue. 2) By mixing $\mathrm{BaO} / \mathrm{BaCO}_{3}, \mathrm{CuO}$ and $\mathrm{SiO}_{2}$ with $\mathrm{PbO}$ as a catalyst, Chinese blue were first generated (over $800^{\circ} \mathrm{C}$ ), but then turned into Chinese purple when the temperature kept increasing without sufficient $\mathrm{SiO}_{2}$. Gan et al., [16] replication experiment shows that by mixing $\mathrm{CuO}$ and $\mathrm{SiO}_{2}$ with lead sources as catalyst, $\mathrm{BaCO}_{3}$ is a better source compared with $\mathrm{BaSO}_{4}$ to produce Chinese blue and purple. Chinese blue can be produced when the temperature reached to $700^{\circ} \mathrm{C}$ by using $\mathrm{BaCO}_{3}$, while temperature needs to reach $1000^{\circ} \mathrm{C}$ to produce Chinese blue by using $\mathrm{BaSO}_{4}$. $\mathrm{PbO}$,
$\mathrm{PbS}$ and $\mathrm{PbCO} 3$ all can be used as catalyst for producing Chinese blue and purple, but $\mathrm{PbCO} 3$ shows better catalytic effect compared with the other two.

The aim of this replication experiment is therefore to explore the different possibilities of how lead-barium glass could have been produced by testing a series of probable recipes with varying proportions of each raw material. This paper emphasizes and explores the significance of sodium in the technological process of lead-barium glass production. This is important because although it has been suggested elsewhere that sodium is necessary to produce $\mathrm{Pb}$-Ba glass, it is noteworthy that many analyses either record low values for $\mathrm{Na}_{2} \mathrm{O}$, or do not report $\mathrm{Na}_{2} \mathrm{O}$, meaning that the role of sodium in the process is not clear. Two hypotheses are tested: (1) whether lead-barium glass can be directly produced by mixing lead, barium and silica sources with controlled ratios, and (2) if it can be produced by mixing natron glass with leadbarium minerals. Moreover, it is also important to understand how different lead and barium minerals could influence the process of glass forming.

\section{Materials and Methods}

The aim of this series of experimental firings was to answer a series of questions:

i) to confirm that melts without a source of sodium did not produce glass at temperatures consistent with ancient glass furnace technologies;

ii) to estimate the minimum amount of sodium required to produce glass;

iii) to test the effects of varying the mineralogy of the various sources of lead and barium.

The raw materials used were barite $\mathrm{BaSO}_{4}$, witherite $\mathrm{BaCO}_{3}$, galena $\mathrm{PbS}$, lead oxide $\mathrm{PbO}$, silica quartz $\mathrm{SiO}_{2}$, lime $\mathrm{CaCO}_{3}$, natron $\mathrm{Na}_{2} \mathrm{CO}_{3} \cdot 10 \mathrm{H}_{2} \mathrm{O}$, sodium feldspar (albite) $\mathrm{Na}_{2} \mathrm{O} \cdot \mathrm{Al}_{2} \mathrm{O}_{3} \cdot 6 \mathrm{SiO}_{2}$, borax $\mathrm{Na}_{2} \mathrm{~B}_{4} \mathrm{O}_{7} \cdot 10 \mathrm{H}_{2} \mathrm{O}$, and copper carbonate $\mathrm{Cu}_{2}(\mathrm{OH})_{2} \mathrm{CO}_{3}$, all purchased as laboratory reagents from either Thermo Fisher Scientific or Potclays (https://www.potclays.co.uk/). All materials are of greater than $99 \%$ purity. In addition, replicated Roman natron glass was provided by Professor Andrew Shortland from Cranfield University. 
In total, 24 different combinations were fired in high-alumina ceramic crucibles, as listed in Table 1 . The weight of each batch was approximately $30 \mathrm{~g}$ in total. For the glass replications a Monometer EF laboratory electric muffle furnace was used and the firing was conducted in air. The heating rate up to the maximum temperature of $1050^{\circ} \mathrm{C}$ during six hours was $5^{\circ} \mathrm{C} / \mathrm{min}$, except in the range $90-110^{\circ} \mathrm{C}$ when a slower heating rate of $1^{\circ} \mathrm{C} / \mathrm{min}$ was used in order to eliminate humidity. The cooling rate was $2.5^{\circ} \mathrm{C} / \mathrm{min}$ down to $700^{\circ} \mathrm{C}$ after which the furnace cooled naturally. The furnace was opened after twelve hours. All experimental mixtures were heated in ceramic crucibles, and the outer layer in contact with the crucible was subsequently removed in order to minimize contamination for subsequent analysis. The first five crucibles (1-5 in Table 1) were to test whether lead-barium glass can be produced directly by mixing a silica source with different combinations of lead and barium minerals. This helps to confirm that sodium is a necessary component for making lead-barium glass. As for lead and barium sources, differences between $\mathrm{BaSO}_{4} \mathrm{vs} \mathrm{BaCO}_{3}$ and $\mathrm{PbO}$ vs $\mathrm{PbS}$ were tested. Crucible 5 additionally contains $\mathrm{CuCO}_{3}$ to produce a green colour. Crucibles 6-11 were designed to test if lead-barium glass can be directly produced by controlled ratios of soda-lime glass with different lead and barium minerals. Differences between the use of $\mathrm{BaSO}_{4}$ vs $\mathrm{BaCO}_{3}$ and $\mathrm{PbO}$ vs $\mathrm{PbS}$ in the crucible charges were again tested. Crucible 7 additionally contains $\mathrm{CuCO}_{3}$ to produce a green colour. Crucible 12 was designed to test if lead-barium glass can be replicated by mixing sodium feldspar (albite) with lead and barium minerals. Crucibles 13-24 can be divided into three groups of four, with each group aimed at replicating one of three published chemical compositions for ancient lead-barium glass, as shown in Table 3 [18,19]. The main difference between the three compositions is the percentage of sodium $\left(1.35 \%, 2.83 \%\right.$ and $\left.9.31 \% \mathrm{Na}_{2} \mathrm{O}\right)$. Each group contains four crucibles, which were designed to test different lead and barium minerals for glass forming. One of the four crucibles in each set was without $\mathrm{Na}_{2} \mathrm{O}$, again to test the importance of sodium in the charge. The chemical composition of replicated Roman glass is shown in Table 3.

After firing and cooling, the crucibles were sectioned by electric saw for cross-sectional observation using SEM-EDS. After carbon coating the sections were analyzed using a JSM 5910 scanning electron microscope (SEM) equipped with an Oxford Instrument INCA 300 energy dispersive analyzer (EDA). Observations were made primarily in secondary electron mode and EDS analysis was performed using a $20 \mathrm{kV}$ accelerating voltage and a live count time of 100 seconds. Primary standards were used to quantify the data. Detail information about primary standards can be found in Supplementary.2, and Table 2 shows the data accuracy and precision by testing Corning standards.

\section{Results}

A detailed description, including photographs, SEM secondary electron images of cross sections and chemical analyses (where available), is given for each sample in Supplementary 3. Table 3 shows the chemical results (by energy dispersive spectrometry) for 23 crucibles, with the omission of crucible 1 , which only retained a limited amount of material after firing.

The results of the experiment can be divided into three broad categories - those which produced transparent glass $(6,7,8,9,10,11,17$, $18,19,20,2122,24)$ those which produced opaque partially vitrified material $(12,13,14,15)$, and those which gave opaque granular material $(2,3,4,5,16,23)$. Crucibles 17 and 18 produced only a thin layer of glass, and their chemical compositions are more close to lead-barium glaze with low $\mathrm{Na}_{2} \mathrm{O}$ concentration [24], probably because a large proportion of the crucible charge was lost due to outgassing of $\mathrm{BaCO}_{3}$ and $\mathrm{Cu}_{2}(\mathrm{OH})_{2} \mathrm{CO}_{3}$. Although crucibles 19 and 20 formed glass, they were considered to be failures since they were high lead glass instead of lead-barium glass according to the EDS analysis (Table 3). The transparent glass is generally produced by those crucible charges with the highest input of $\mathrm{Na}_{2} \mathrm{O}$, which is discussed in more detail below. All of
Table 2

Precisions and accuracies for major and minor elements based on Corning A, B, and D standards [6].

\begin{tabular}{|c|c|c|c|c|c|c|}
\hline Standard & Elements & Certified & $\begin{array}{l}\text { Measured } \\
(n=20)\end{array}$ & \%Error & S.D. & \%R.S.D. \\
\hline \multirow[t]{10}{*}{ Corning A } & $\mathrm{Na}$ & 14.3 & 12.4 & 15.4 & 0.1 & 1.0 \\
\hline & $\mathrm{Mg}$ & 2.7 & 2.4 & 9.8 & 0.1 & 2.6 \\
\hline & $\mathrm{Al}$ & 1.0 & 0.8 & 25.2 & 0.1 & 6.0 \\
\hline & $\mathrm{Si}$ & 67.1 & 69.3 & -3.2 & 0.3 & 0.5 \\
\hline & $\mathrm{K}$ & 2.9 & 3.1 & -8.1 & 0.1 & 1.7 \\
\hline & $\mathrm{Ca}$ & 5.0 & 5.2 & -2.9 & 0.1 & 1.5 \\
\hline & $\mathrm{Ti}$ & 0.8 & 0.9 & -6.6 & 0.0 & 5.0 \\
\hline & $\mathrm{Cu}$ & 1.2 & 1.2 & -4.3 & 0.1 & 6.0 \\
\hline & $\mathrm{Ba}$ & 0.6 & 0.6 & 1.4 & 0.1 & 10.3 \\
\hline & $\mathrm{Pb}$ & 0.1 & 0.0 & / & 0.0 & I \\
\hline \multirow[t]{10}{*}{ Corning B } & $\mathrm{Na}$ & 17.0 & 14.7 & -13.4 & 0.2 & 1.3 \\
\hline & $\mathrm{Mg}$ & 1.0 & 0.9 & -8.4 & 0.0 & 3.7 \\
\hline & $\mathrm{Al}$ & 4.4 & 3.8 & -13.6 & 0.1 & 1.4 \\
\hline & $\mathrm{Si}$ & 62.3 & 64.7 & 3.9 & 0.3 & 0.5 \\
\hline & $\mathrm{K}$ & 1.0 & 1.2 & 17.5 & 0.0 & 2.3 \\
\hline & $\mathrm{Ca}$ & 8.6 & 9.0 & 5.1 & 0.0 & 0.5 \\
\hline & $\mathrm{Ti}$ & 0.1 & 0.0 & / & 0.0 & / \\
\hline & $\mathrm{Cu}$ & 2.7 & 2.9 & 8.7 & 0.1 & 3.4 \\
\hline & $\mathrm{Ba}$ & 0.1 & 0.0 & / & 0.0 & / \\
\hline & $\mathrm{Pb}$ & 0.6 & 0.9 & 39.7 & 0.1 & 10.0 \\
\hline \multirow[t]{10}{*}{ Corning D } & $\mathrm{Na}$ & 1.2 & 1.1 & 8.3 & 0.1 & 5.0 \\
\hline & $\mathrm{Mg}$ & 3.9 & 3.6 & 10.5 & 0.1 & 1.5 \\
\hline & $\mathrm{Al}$ & 5.3 & 4.5 & 17.8 & 0.1 & 1.4 \\
\hline & $\mathrm{Si}$ & 55.5 & 55.1 & 0.7 & 0.3 & 0.6 \\
\hline & $\mathrm{K}$ & 11.3 & 11.7 & -3.4 & 0.1 & 1.1 \\
\hline & $\mathrm{Ca}$ & 14.8 & 14.4 & 2.9 & 0.2 & 1.1 \\
\hline & $\mathrm{Ti}$ & 0.4 & 0.4 & -10.4 & 0.1 & 17.2 \\
\hline & $\mathrm{Cu}$ & 0.4 & 0.4 & 0.9 & 0.1 & 14.1 \\
\hline & $\mathrm{Ba}$ & 0.5 & 0.4 & 16.4 & 0.0 & 5.0 \\
\hline & $\mathrm{Pb}$ & 0.5 & 0.4 & 9.4 & 0.0 & 10.3 \\
\hline
\end{tabular}

the samples made with the synthetic Roman glass (crucibles 6-11) produced transparent glass, apart from the sample made with $\mathrm{PbS}(8$, which produced black glass and a thick layer of white $\mathrm{BaSO}_{4}$ ). Those glasses made using Roman glass with $\mathrm{BaCO}_{3}$ tended to be yellowish in colour, whereas those with Roman glass and $\mathrm{BaSO}_{4}$ were greenish. Crucibles charged with $\mathrm{SiO}_{2}, \mathrm{PbO}, \mathrm{CaCO}_{3}, \mathrm{Na}_{2} \mathrm{CO}_{3}$ and either $\mathrm{BaCO}_{3}$ $(17,21)$ or $\mathrm{BaSO}_{4}(19,22)$ all produced translucent glass. Crucible 18 is somewhat exceptional, in that it is the only one to produce transparent glass which contained no $\mathrm{Na}_{2} \mathrm{CO}_{3}$. It does have a high proportion of $\mathrm{PbO}$ (and some $\mathrm{Cu}_{2}(\mathrm{OH})_{2} \mathrm{CO}_{3}$ ) which presumably provided sufficient flux to produce a glass. Crucible 20 used $\mathrm{PbS}$ as the lead source, and gave a multilayered product which included a yellow transparent glass as well as a black and green layer. Crucible 24, in which the sodium source was borax $\mathrm{Na}_{2} \mathrm{~B}_{4} \mathrm{O}_{7} \cdot 10 \mathrm{H}_{2} \mathrm{O}$ also produced a greenish-yellow transparent glass. Our analyses for crucibles 19 and 20 shows that they are high lead glasses with only $1 \%$ barium oxide.

The group which produced white or ivory coloured partially vitrified opaque material (12-15) in general had a lower sodium and higher silica content than those in the above group. The least vitrified material $(2-5,16,23)$ retained a granular appearance, and had either no or very low sodium.

\section{Discussion}

\subsection{The prerequisite of a sodium source}

$\mathrm{PbO}$ is classified as an intermediate in terms of glass structure, meaning that it cannot itself form a glass, but that it can enter the network of other glass-forming oxides (in this case, $\mathrm{SiO}_{2}$ ). When the $\mathrm{PbO}$ concentration is above c. $50 \mathrm{~mol} \%$, the co-ordination number of $\mathrm{Pb}$ is about 3 , and $\mathrm{PbO}$ switches from being a network modifier to a network former, in which the network consists of $\mathrm{PbO}_{3}{ }^{2-}$ trigonal pyramids linked to $\mathrm{SiO}_{4}{ }^{2-}$ tetrahedra [25]. As shown in Fig. 1, the 
Table 3

EDS semi-quantitative results (wt.\%) for 23 crucibles

\begin{tabular}{|c|c|c|c|c|c|c|c|c|c|c|c|c|c|}
\hline Crucible & $\mathrm{Na}_{2} \mathrm{O}$ & $\mathrm{MgO}$ & $\mathrm{Al}_{2} \mathrm{O}_{3}$ & $\mathrm{SiO}_{2}$ & $\mathrm{P}_{2} \mathrm{O}_{5}$ & $\mathrm{SO}_{3}$ & $\mathrm{~K}_{2} \mathrm{O}$ & $\mathrm{CaO}$ & $\mathrm{TiO}_{2}$ & $\mathrm{CuO}$ & $\mathrm{BaO}$ & $\mathrm{PbO}$ & Description \\
\hline 2 & - & - & - & 51.5 & - & 1.0 & - & - & 1.7 & - & 5.8 & 40.1 & Pale green opaque granular material \\
\hline 3 & - & - & 0.2 & 23.7 & - & 8.0 & - & - & 1.5 & - & 18.6 & 48.0 & White opaque granular material \\
\hline 4 & - & - & - & 70.4 & - & - & - & - & - & - & 4.9 & 24.7 & White opaque granular material, partially vitrified \\
\hline 5 & - & - & - & 47.2 & - & - & - & - & 0.3 & 3.9 & 11.1 & 37.5 & Dark blue opaque granular material \\
\hline 6 & 6.8 & 0.8 & 1.6 & 34.8 & - & - & 0.6 & 3.2 & - & - & 8.9 & 43.3 & Yellowish transparent glass with cracks \\
\hline 7 & 6.2 & 0.8 & 1.4 & 32.8 & - & - & 0.6 & 3.1 & - & 3.7 & 8.5 & 42.9 & Blue transparent glass with cracks \\
\hline 8 & 6.5 & 1.1 & 1.6 & 44.6 & - & - & 0.7 & 4.3 & - & - & 8.6 & 32.7 & Black transparent glass with a layer of white dendritic crystalline material \\
\hline 9 & 7.1 & 0.9 & 1.7 & 44.3 & - & - & 0.9 & 4.5 & - & - & 5.6 & 35.0 & Greenish transparent glass with a layer of white flocculent material \\
\hline 10 & 7.8 & 0.8 & 1.4 & 37.9 & - & - & 0.6 & 3.5 & - & - & 17.1 & 31.0 & $\begin{array}{l}\text { Yellowish transparent glass with cracks and partial layer of white opaque } \\
\text { crystals }\end{array}$ \\
\hline 11 & 6.9 & 0.9 & 1.8 & 39.3 & - & - & 0.6 & 3.8 & - & - & 5.9 & 41.0 & Greenish transparent glass with white opaque layer on top \\
\hline 12 & 3.9 & - & 9.7 & 33.4 & - & - & 0.4 & 0.7 & - & - & 10.6 & 41.4 & Ivory opaque partially vitrified material with air bubbles on the top layer \\
\hline 13 & 1.0 & - & - & 60.7 & - & - & - & 1.1 & - & - & 11.0 & 26.3 & White opaque partially vitrified material with big air holes \\
\hline 14 & - & - & - & 64.9 & - & - & - & 1.7 & - & - & 11.4 & 22.1 & White opaque partially vitrified material with big air holes \\
\hline 15 & 1.1 & - & - & 69.0 & 0.5 & - & - & 1.5 & - & - & 2.5 & 25.5 & White opaque partially vitrified material \\
\hline 16 & 1.1 & - & - & 67.4 & - & 1.4 & - & 1.2 & 0.6 & - & 4.9 & 23.5 & Pale blue opaque granular material with large bubbles \\
\hline 17 & 2.5 & - & 0.2 & 35.4 & - & - & 0.4 & 2.0 & - & 3.2 & 9.0 & 47.3 & Emerald green translucent glass \\
\hline 18 & - & - & - & 35.3 & - & - & - & 1.8 & - & 3.5 & 8.0 & 51.5 & Emerald green translucent glass \\
\hline 19 & 1.9 & - & - & 37.3 & - & - & 0.1 & 1.9 & - & 3.0 & 1.7 & 54.1 & $\begin{array}{l}\text { Green transparent glass with a layer of green and white opaque crystalline } \\
\text { material }\end{array}$ \\
\hline 20 & 1.5 & - & - & 37.6 & - & - & - & 1.8 & - & 1.3 & 1.1 & 56.8 & $\begin{array}{l}\text { Yellow transparent glass with a layer of green and white opaque } \\
\text { crystalline material }\end{array}$ \\
\hline 21 & 7.5 & - & - & 48.1 & - & - & 0.3 & 1.4 & - & - & 14.2 & 28.6 & Greenish transparent glass with cracks \\
\hline 22 & 5.8 & - & - & 59.6 & - & - & - & 1.2 & - & - & 6.0 & 27.4 & $\begin{array}{l}\text { Greenish transparent glass with white opaque crystalline material on the } \\
\text { top surface }\end{array}$ \\
\hline 23 & - & - & - & 51.1 & - & - & - & 1.1 & 1.1 & - & 20.2 & 26.6 & White granular opaque material with big air holes \\
\hline 24 & 8.5 & - & 0.7 & 46.0 & - & - & 0.6 & 1.0 & - & - & 12.1 & 31.1 & Greenish-yellow transparent glass \\
\hline Natron glass & 15.9 & 1.6 & 2.9 & 70.9 & - & - & 0.8 & 7.9 & - & - & - & - & Transparent \\
\hline White glass Bead & 1.4 & 0.2 & 1.1 & 55.6 & 0.1 & - & 1.1 & 1.3 & 0.1 & 0.4 & 11.6 & 26.6 & [10] \\
\hline Green glass Bi disk & 2.8 & 0.3 & 1.2 & 34.8 & 0.1 & - & 0.3 & 1.7 & 0.0 & 1.5 & 8.5 & 48.5 & [10] \\
\hline Glass Earring & 9.3 & 2.2 & 1.7 & 45.9 & - & - & 0.3 & 0.8 & - & - & 12.9 & 27.3 & {$[31]$} \\
\hline
\end{tabular}

Table 4

The comparison of calculated and measured chemical compositions for crucibles formed glass

\begin{tabular}{|c|c|c|c|c|}
\hline Crucible & Charge & Result & $\begin{array}{l}\% \mathrm{Na}_{2} \mathrm{O} \text { in } \\
\text { Charge }\end{array}$ & $\% \mathrm{Na}_{2} \mathrm{O}$ in Product \\
\hline \multicolumn{5}{|c|}{ Transparent glass } \\
\hline 6 & $10 \mathrm{BaCO}_{3} / 40 \mathrm{PbO} / 50 \mathrm{RG}$ & Yellowish transparent glass with cracks & 8.0 & 6.8 \\
\hline 7 & $10 \mathrm{BaCO}_{3} / 40 \mathrm{PbO} / 45 \mathrm{RG} / 5 \mathrm{Cu}_{2}(\mathrm{OH})_{2} \mathrm{CO}_{3}$ & Blue transparent glass with cracks & 7.2 & 6.2 \\
\hline 8 & $10 \mathrm{BaSO}_{4} / 40 \mathrm{PbS} / 50 \mathrm{RG}$ & $\begin{array}{l}\text { Black transparent glass with a layer of white dendritic crystalline } \\
\text { material }\end{array}$ & 8.0 & 6.5 \\
\hline 9 & $10 \mathrm{BaSO}_{4} / 40 \mathrm{PbO} / 50 \mathrm{RG}$ & $\begin{array}{l}\text { Greenish transparent glass with a layer of white flocculent } \\
\text { material }\end{array}$ & 8.0 & 7.1 \\
\hline 10 & $20 \mathrm{BaCO}_{3} / 30 \mathrm{PbO} / 50 \mathrm{RG}$ & $\begin{array}{l}\text { Yellowish transparent glass with cracks and partial layer of white } \\
\text { opaque crystals }\end{array}$ & 8.0 & 7.8 \\
\hline 11 & $10 \mathrm{BaSO}_{4} / 30 \mathrm{PbO} / 60 \mathrm{RG}$ & Greenish transparent glass with white opaque layer on top & 9.6 & 6.9 \\
\hline 17 & $33 \mathrm{SiO}_{2} / 10 \mathrm{BaCO}_{3} / 45 \mathrm{PbO} / 3 \mathrm{CaCO}_{3} / 5 \mathrm{Na}_{2} \mathrm{CO}_{3}$ & Emerald green translucent glass & 2.9 & 2.5 \\
\hline 18 & $33 \mathrm{SiO}_{2} / 10 \mathrm{BaCO}_{3} / 50 \mathrm{PbO} / 3 \mathrm{CaCO}_{3} / 4 \mathrm{Cu}_{2}(\mathrm{OH})_{2} \mathrm{CO}_{3}$ & Emerald green translucent glass & 0.0 & 0.0 \\
\hline 19 & $\begin{array}{l}30 \mathrm{SiO}_{2} / 15 \mathrm{BaSO}_{4} / 45 \mathrm{PbO} / 2.5 \mathrm{CaCO}_{3} / 4 \mathrm{Na}_{2} \mathrm{CO}_{3} / 3.5 \\
\mathrm{Cu}_{2}(\mathrm{OH})_{2} \mathrm{CO}_{3}\end{array}$ & $\begin{array}{l}\text { Green transparent glass with a layer of green and white opaque } \\
\text { crystalline material }\end{array}$ & 2.3 & 1.9 \\
\hline 20 & $\begin{array}{l}30 \mathrm{SiO}_{2} / 10 \mathrm{BaCO}_{3} / 50 \mathrm{PbS} / 2.5 \mathrm{CaCO}_{3} / 4 \mathrm{Na}_{2} \mathrm{CO}_{3} / 3.5 \\
\mathrm{Cu}_{2}(\mathrm{OH})_{2} \mathrm{CO}_{3}\end{array}$ & $\begin{array}{l}\text { Yellow transparent glass with a layer of green and white opaque } \\
\text { crystalline material }\end{array}$ & 2.3 & 1.5 \\
\hline 21 & $43 \mathrm{SiO}_{2} / 15 \mathrm{BaCO}_{3} / 25 \mathrm{PbO} / 2 \mathrm{CaCO}_{3} / 15 \mathrm{Na}_{2} \mathrm{CO}_{3}$ & Greenish transparent glass with cracks & 8.8 & 7.5 \\
\hline 22 & $43 \mathrm{SiO}_{2} / 15 \mathrm{BaSO}_{4} / 25 \mathrm{PbO} / 2 \mathrm{CaCO}_{3} / 15 \mathrm{Na}_{2} \mathrm{CO}_{3}$ & $\begin{array}{l}\text { Greenish transparent glass with white opaque crystalline material } \\
\text { on the top surface }\end{array}$ & 8.8 & 5.8 \\
\hline 24 & $30 \mathrm{SiO}_{2} / 10 \mathrm{BaCO}_{3} / 20 \mathrm{PbO} / 1 \mathrm{CaCO}_{3} / 39 \mathrm{Na}_{2} \mathrm{~B}_{4} \mathrm{O}_{7} \cdot 12 \mathrm{H}_{2} \mathrm{O}$ & Greenish-yellow transparent glass & 6.3 & 8.5 \\
\hline \multicolumn{5}{|c|}{ Opaque partially vitrified } \\
\hline 12 & $10 \mathrm{BaCO}_{3} / 40 \mathrm{PbO} / 50$ albite & $\begin{array}{l}\text { Ivory opaque partially vitrified material with air bubbles on the } \\
\text { top layer }\end{array}$ & 5.9 & 3.9 \\
\hline 13 & $55 \mathrm{SiO}_{2} / 15 \mathrm{BaCO}_{3} / 25 \mathrm{PbO} / 2.5 \mathrm{CaCO}_{3} / 2.5 \mathrm{Na}_{2} \mathrm{CO}_{3}$ & White opaque partially vitrified material with big air holes & 1.5 & 1.0 \\
\hline 14 & $57 \mathrm{SiO}_{2} / 15 \mathrm{BaCO}_{3} / 25 \mathrm{PbO} / 3 \mathrm{CaCO}_{3}$ & White opaque partially vitrified material with big air holes & 0.0 & 0.0 \\
\hline 15 & $55 \mathrm{SiO}_{2} / 15 \mathrm{BaSO}_{4} / 25 \mathrm{PbO} / 2.5 \mathrm{CaCO}_{3} / 2.5 \mathrm{Na}_{2} \mathrm{CO}_{3}$ & White opaque partially vitrified material & 1.5 & 1.1 \\
\hline \multicolumn{5}{|c|}{ Opaque granular } \\
\hline 2 & $40 \mathrm{SiO}_{2} / 15 \mathrm{BaCO}_{3} / 45 \mathrm{PbO}$ & Pale green opaque granular material & 0.0 & 0.0 \\
\hline 3 & $40 \mathrm{SiO}_{2} / 15 \mathrm{BaSO}_{4} / 45 \mathrm{PbS}$ & White opaque granular material & 0.0 & 0.0 \\
\hline 4 & $60 \mathrm{SIO}_{2} / 10 \mathrm{BaCO}_{3} / 30 \mathrm{PbO}$ & White opaque granular material, partially vitrified & 0.0 & 0.0 \\
\hline 5 & $35 \mathrm{SiO}_{2} / 15 \mathrm{BaCO}_{3} / 45 \mathrm{PbO} / 5 \mathrm{Cu}_{2}(\mathrm{OH})_{2} \mathrm{CO}_{3}$ & Dark blue opaque granular material & 0.0 & 0.0 \\
\hline 16 & $55 \mathrm{SiO}_{2} / 15 \mathrm{BaCO}_{3} / 25 \mathrm{PbS} / 2.5 \mathrm{CaCO}_{3} / 2.5 \mathrm{Na}_{2} \mathrm{CO}_{3}$ & Pale blue opaque granular material with large bubbles & 1.5 & 1.1 \\
\hline 23 & $48 \mathrm{SiO}_{2} / 20 \mathrm{BaCO}_{3} / 30 \mathrm{PbO} / 2 \mathrm{CaCO}_{3}$ & White granular opaque material with big air holes & 0.0 & 0.0 \\
\hline
\end{tabular}




\begin{tabular}{|l|}
\hline wt\% in charge \\
\hline$\times$ Failure \\
Success \\
\hline
\end{tabular}

\begin{tabular}{|l|}
\hline wt\% in product \\
\hline$\times$ Failure \\
Success \\
\hline
\end{tabular}

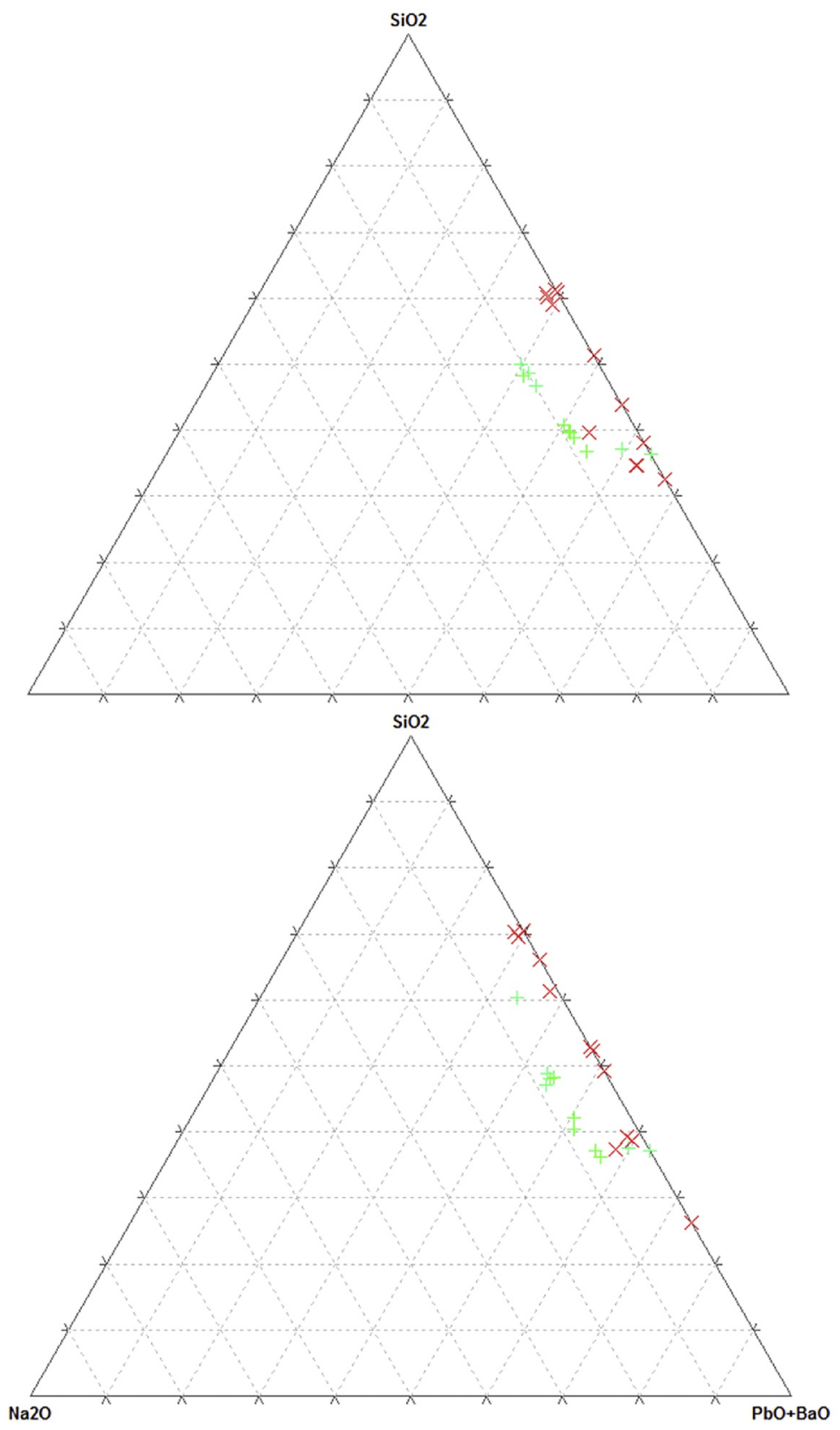

Fig. 2. $\mathrm{SiO}_{2}-\mathrm{Na}_{2} \mathrm{O}-\mathrm{PbO}+\mathrm{BaO}$ phase diagrams of components in charge and in product previously analyzed examples of Chinese $\mathrm{Pb}$-Ba glass tend to contain amounts of $\mathrm{Na}_{2} \mathrm{O}$ up to $10 \%$. The question to be addressed here is why, with so much $\mathrm{PbO}$ available to act as a network modifier, does $\mathrm{Na}_{2} \mathrm{O}$ appear to be necessary to form lead-barium glass? Table 4 compares calculated sodium compositions according to the recipes presented in Table 1 with the measured chemical compositions for each crucible (from Table 3). The calculated value was obtained by mathematically converting each component in the charge into an oxide formulation, and then normalizing the sum of these oxides to $100 \%$. Fig. 2 shows the $\mathrm{SiO}_{2}-\mathrm{Na}_{2} \mathrm{O}-\mathrm{PbO}+\mathrm{BaO}$ phase diagrams of components in charge and in product. As shown, a certain amount of $\mathrm{Na}_{2} \mathrm{O}$ plays an essential role for lead-barium glass forming compared with failures. Transparent glass (or crucibles containing a component of transparent glass) was formed most easily when the charge contained high levels of $\mathrm{Na}_{2} \mathrm{O}-$ apart from crucible 17 and 18 (with low or no $\mathrm{Na}_{2} \mathrm{O}$ ), all charges contained greater than $7 \%$ being more typical. Conversely, the crucibles which did not vitrify contained $<1.5 \% \mathrm{Na}_{2} \mathrm{O}$, with the exception of crucible 12 , which contained $5.92 \% \mathrm{Na}_{2} \mathrm{O}$ in the form of albite $\left(\mathrm{NaAlSi}_{3} \mathrm{O}_{8}\right)$. It is therefore clear that under the conditions of this experiment sodium can facilitate glass formation in the lead-barium-silica system.

The data in Table 4 and Fig. 2 show that the measured $\mathrm{Na}_{2} \mathrm{O} \%$ are lower than the calculated $\mathrm{Na}_{2} \mathrm{O} \%$, which could be detecting error or a flux loss during the melting process. Still, it is noticeable that the crucibles using $\mathrm{BaSO}_{4}$, such as 11 and 22, show a higher loss of $\mathrm{Na}_{2} \mathrm{O}$ (about 3\%). According to the EDS chemical data and the mapping results (Supplementary 3), the white material in crucibles 11 and 22 contain a certain amount of $\mathrm{Na}_{2} \mathrm{SO}_{4}$, which would explain the lower values of $\mathrm{Na}_{2} \mathrm{O}$ in the glass. Nevertheless, it is immediately apparent that all the samples which produced transparent glass generally contain more than $7 \% \mathrm{Na}_{2} \mathrm{O}$, whereas comparison with Fig. 1 shows that most of the lead-barium glass analyzed to date appears to have values around $2 \%$. As noted above, there are two other possible reasons why $\mathrm{Na}_{2} \mathrm{O} \%$ might be underestimated in the literature: i), XRF and PIXE analysis can underestimate $\mathrm{Na}_{2} \mathrm{O} \%$, and ii) weathering effects can result in the loss 
of $\mathrm{Na}_{2} \mathrm{O}$.

There are three possibilities for the deliberate addition of sodium to these Pb-Ba glasses:

i) direct addition of a mineral which contains sodium (e.g., natron, albite, mirabilite),

ii) direct addition of a soda-rich plant ash,

iii) indirect addition, via the re-use of glass which already contains sodium.

There is no archaeological evidence to suggest that Chinese glass makers could produce soda-lime glass during the Warring States period and the Han Dynasty, and nor are there any literary sources which suggest that other contemporaneous Chinese vitreous materials used a mineral or plant-based sodium source as the flux during this period. According to Chinese chronicle Beishi 北史 (History of the Northern Dynasties), during the Wei Taiwu period (408 - $452 \mathrm{CE}$ ), the inhabitants of Middle Asia who were in trade with China taught the Chinese to melt and to mould coloured glass [26-31]. This is the earliest documentation about glass making in China. Thus, although there are numerous soda-lime silica glass beads found in early China, they are all assumed to be imported from Western Asia [28,29,33]. Commonly used flux for the silicate materials during the Warring States and the Han period were lead and wood ash, such as lime glaze and and wood ash glaze. As for Chinese lime based ceramic glazes, the source of lime initially was from wood ash, and subsequently replaced by limestone [32]. The low-temperature lead-glazed ceramics (and lead-barium glazed) appeared no latter than the Han Dynasty, and were only used for burial and architectural objects $[34,35,36]$. According to the published data for lead-barium glass, the potassium and magnesium concentrations (medians $0.57 \%$ and $0.53 \%$ respectively from the published literature) are too low to represent a plant ash flux [37], where typical values would be both greater than $1.5 \%$ respectively [38]. This effectively rules out the direct production of $\mathrm{Pb}-\mathrm{Ba}$ glass using soda-rich plant ash, as was common in Western Asia. The known mineral sodarich sources used in ancient western Eurasian glass could either be a natron (evaporate) source, such as that from Egypt, or a reh (saline soil) source from the Indo-pacific region, both of which have analogous occurrences in China. A mineral source of sodium cannot therefore be ruled out in the production of $\mathrm{Pb}-\mathrm{Ba}$ glass, and both the experiments reported here (crucibles 17-22, 24) and those of previous researchers $[14,39,40]$ have shown that this is plausible. There is, however, little evidence that the Chinese knew the function of mineral forms of sodium in the production of vitreous artefacts during this period. Also, the minor element composition of $\mathrm{Pb}$ - $\mathrm{Ba}$ glass (i.e., $\mathrm{K} 2 \mathrm{O}, \mathrm{CaO}, \mathrm{MgO}, \mathrm{Al}_{2} \mathrm{O}_{3}$, $\mathrm{TiO}_{2}, \mathrm{Fe}_{2} \mathrm{O}_{3}$ ) could also be explained by the use of imported soda-lime glass as the sodium source. The Levantine coast appears to have been the location of large-scale glass making in antiquity [41], which could be source of soda-lime glass.

\subsection{Opaque Glass}

Chinese $\mathrm{Pb}-\mathrm{Ba}$ glass can be either transparent or opaque. Many of the products listed in Table 3 show that a clear glass is produced but with an opaque crystalline material on the surface (crucibles 8-11, 19, 20,22 ). In most cases this white material is identified as $\mathrm{BaSO}_{4}$ and $\mathrm{BaSi}_{2} \mathrm{O}_{5}$ from the stoichiometry of the chemical analysis (Supplementary 3: crucible 11). According to this replication experiment, it is apparent that more white opaque material can be generated by mixing $\mathrm{BaSO}_{4}$ and $\mathrm{PbO}$ with natron glass rather than by using $\mathrm{BaCO}_{3}$ as the barium source. It is possible, therefore, that both $\mathrm{BaSO}_{4}$ and $\mathrm{BaCO}_{3}$ were used selectively in the past to control for the degree of opacity. In our work, the crucibles with $\mathrm{BaSO}_{4}$ generated both $\mathrm{BaSi}_{2} \mathrm{O}_{5}$ and unmelted $\mathrm{BaSO}_{4}$ which can function as opacifiers, although in our replications $\mathrm{BaSO}_{4}$ forms on the top of the glass rather than being uniformly dispersed within the glass. It might not be possible to produce white opaque lead-barium glass during primary glass production due to potential separation of the opaque materials during the slow cooling down process. As colouring, clarifying or opacifying agents could be added to the glass batch during the secondary production [42], we suggest that the products of the primary melting might have needed to be re-melted to mix the opacifier into the glass.

According to Table 4 , the loss of $\mathrm{Na}_{2} \mathrm{O}$ is lower than $3 \%$, then all other concentrations indeed go up when the data are normalized to $100 \%$. It particularly affects $\mathrm{SiO}_{2}, \mathrm{BaO}$ and $\mathrm{PbO}$ (as the major constituents), but they only go up about $1 \%$ (absolute) for each one. Thus, such small overestimates of $\mathrm{SiO}_{2}, \mathrm{BaO}$ and $\mathrm{PbO}$ could not make much difference for the formation of lead-barium glass. Still, in some extreme cases, when lead-barium glass is badly weathered, a layer of $\mathrm{PbCO}_{3}$ (secondary formed) and $\mathrm{BaSO}_{4}$ (probably by leaching) will formed on the lead-barium glass surface [43].

In this replication experiment, we did not observe any $\mathrm{PbO}$ leaching effect. As for crucibles used $\mathrm{BaSO}_{4}$ and formed glass, a layer of white opacifier remains on the surface glass identified as $\mathrm{BaSO}_{4}$ and $\mathrm{BaSi}_{2} \mathrm{O}_{5}$. Thus, there is a small loss of $\mathrm{BaO}$ in glass phase.

\section{Conclusions}

The direct mixing and firing of lead and barium minerals with silica cannot easily produce lead-barium glass, and the chemical analysis of a large number of Chinese $\mathrm{Pb}$-Ba glasses show that the $\mathrm{Na}_{2} \mathrm{O}$ concentration is typically between 2 and $10 \%$, suggesting that a source of sodium was deliberately included in the melt as an additional flux. The use of o source of sodium to successfully achieve lead-barium glasses is connected with the fact that it could also lower the melting point of this kind of glasses. Although mineral sources of soda could have been used, no Chinese historical records during the Warring States period to the Han Dynasty mention the use of a sodium source as flux. The experiments reported here have shown that lead-barium glass can easily be achieved by mixing imported soda-lime glass with mineral sources of $\mathrm{PbO}$ and either $\mathrm{BaCO}_{3}$ or $\mathrm{BaSO}_{4}$. The direct use of $\mathrm{PbS}$ was less successful, but in practice prior roasting would have converted this to the oxide form. If we accept that soda-lime silica glass was imported into China from the west during the Warring States period (which it must have been if we believe that China did not make soda-lime silica glass), then it is easy to see how some of this material could have been used as a raw material to locally make $\mathrm{Pb}$-Ba glass. The impetus for this would probably have been the desire to produce synthetics jade. The disappearance of this type of glass could then subsequently be explained by the disruption of trade at the end of the Han Dynasty, in which no more primary glass was imported across the Silk Roads. The frequent change of dynasties after the Han Dynasty might have played a crucial role in these developments.

\section{Authors' contributions}

Qian Ma wrote the main manuscript, and the replication experiment and SEM-EDS analysis was done by Qian Ma.

Mark Pollard supervised Qian Ma for this project and revised the manuscript when Qian Ma finished the draft.

Dennis Braekmans supervised Qian Ma for the replication experiment.

Andrew Shortland helped get permission to conduct this experiment in Cranfield University.

\section{Declaration of Competing Interest}

The authors declare that they have no known competing financial interests or personal relationships that could have appeared to influence the work reported in this paper. 


\section{Acknowledgements}

The authors would like to thank Dr Chris Doherty (Oxford University) for his support regarding the SEM-EDS analysis and Adrian Mustey (Cranfield University) for his assistance with the heating experiment

\section{Supplementary materials}

Supplementary material associated with this article can be found, in the online version, at doi:10.1016/j.jnoncrysol.2020.120409.

\section{Bibliography}

[1] R. Abd-Allah, Chemical characterisation and manufacturing technology of late Roman to early Byzantine glass from Beit Ras/Capitolias, Northern Jordan, J. Archaeol. Sci. 37 (2010) 1866-1874. 10.1016/j.jas.2010.02.004 .

[2] N. Ali, R. Abd-Allah, The Authentication and Characterization of Glass Objects Excavated from Telles-Sukhnah, Jordan, Mediterr. Archaeol. Archaeom. 15 (2015).

[3] J. An, Historical Narrative of Glass Ware, Encyclopedia of China Publishing House, Beijing, 1998.

[4] Z. Bao, A General Discussion on the Historical Function of the Ancient Silk road, Stud. Cult. \& Art. 8 (2015) 20-30.

[5] M.A. Bezboradov, YU.A. Zadneprovskii, Ancient and Medieval glass of Central Asia, in: M. Levey (Ed.), Presented at the Archaeological Chemistry: a symposium, 3rd, University of Pennsylvania Press, Philadelphia, Atlantic City, NJ, 1967, pp. 29-57.

[6] R.H. Brill, B.A. Rising, Chemical analyses of early glasses, 1999 Corning Museum of Glass, Corning, N.Y.

[7] R.H. Brill, J.F. Wosinski, Physical Properties of Early Chinese Glasses, in: Scientific Research in Early Chinese Glass, 1984, pp. 109-117 Corning glass Museum, New York.

[8] Q. Chen, A Primary Study on Simulated Sintering Experiment of Manmade Barium Silicate Products in Ancient, 2014 China (Masters Dissertation). University of Science and Technology of China, Hefei.

[9] J. Cui, X. Wu, B. Huang, Chemical and lead isotope analysis of some lead-barium glass wares from the Warring States Period, unearthed from Chu tombs in Changde City, Hunan Province, China, J. Archaeol. Sci. 38 (2011) 1671-1679.

[10] J. Cui, X. Wu, Y. Tan, Y. Wang, Chemical Analysis of Ancient Wares Unearthed from Chu Cemeteries of the Warring State Period in the Drainage Area of the Yuanshui River, Hunan Province, J. Chin. Ceram. Soc. 37 (2009) 1909-1913.

[11] E.W. Fitzhugh, L.A. Zycherman, A purple barium copper silicate pigment from early China, Stud. Conserv. 37 (1992) 145-154. 10.1179/sic.1992.37.3.145

[12] Gan, F., 2016. The History of Technology Development of Ancient Chinese glass. Shanghai Scientific \& Technical Publishers, shanghai.

[13] F. Gan, The Silk Road and Ancient Chinese Glasses, Chinese Journal of Nature. J. Nat. 28 (2006) 253-260.

[14] F. Gan, Development of Chinese Ancient Glass, Shanghai Scientific \& Technical Publishers, Shanghai, 2005.

[15] F. Gan, H. Cheng, Y. Hu, B. Ma, D. Gu, Analysis of the Chinese Earliest Eye Beads unearthed from Xujialing, Scinece China Press, Xichuan, Henan Province, 2009, pp. 787-792 39.

[16] F. Gan, H. Cheng, Q. Li, The Origin of Chinese Ancient Glass- Analysis of the Earliest Chinese glass 37 Scinece China Press, 2007, pp. 382-391.

[17] F. He, M. Wan, The Culture Exchange Between Ancient China and the West, The Commercial Press, Beijing, 1998.

[18] Henderson, J., 2013. Ancient glass: an interdisciplinary exploration. Cambridge University Press.

[19] D. Hou, The Investigation of the Chu Glass Production, 1989, pp. 24-29 Cult. Relics Cent. China.
[20] J.W. Lankton, L. Dussubieux, Early glass in Asian maritime trade: a review and an interpretation of compositional analyses, J. Glass Stud. (2006) 121-144.

[21] J.W. Lankton, L. Dussubieux, B. Gratuze, Glass from Khao Sam Kaeo: transferred technology for an early Southeast Asian exchange network, Bull. LÉcole Fr. Extrême-orient. (2006) 317-351.

[22] M. Li, Simulated Experiment of Faience and Analysis of Lead Barium Glass During the Warring State and the Han Dynasty, 2014 (Masters Dissertation). Beijing University of Chemical Technology, Beijing.

[23] O. Li, J. Dong, B. Su, G. Chen, S. Liu, D. Gu, Non-destructive Analysis of the Warring States Glass Beads Unearthed from Jingzhou, Hubei by pXRF and Discussions on Relative Issues [J], Dunhuang Res. 1 (2013) 92-97.

[24] Q. Li, H. Zhou, J. Huang, F. Gan, B. Zhang, Chemical Composition Analytic Results of Ancient Chinese Compound Eye-beads, Hanjiang Archaeol. (2005) 79-83.

[25] X. Li, Analysis and Simulated Experiment of Ancient Glass Unearthed from Suzao Sites, 2010 Hubei Province (Masters Dissertation). University of Science and Technology of China, Hefei.

[26] X. Li, About the Origin of Chinese Lead-Barium glass, Stud. Hist. Nat. Sci. 15 (1996) $144-150$.

[27] J. Liu, The Commodity Circulation of the Ancient Silk Road, 2012, pp. 21-22 Lantai World.

[28] A.M. Pollard, N.D. Wood, J.S. Olin, M.J. Blackman (Eds.), Development of Chinese porcelain technology at Jingdezhen, Washington DC, 1986, pp. 105-114 Proceedings of the 24th International Archaeometry Symposium.

[29] Y. Qin, Y. Wang, X. Chen, H. Li, Y. Xu, X. Li, The research of burning ancient Chinese lead-barium glass by using mineral raw materials, J. Cult. Herit. 21 (2016) 796-801. 10.1016/j.culher.2016.04.003

[30] Th. Rehren, I.C. Freestone, Ancient glass: from kaleidoscope to crystal ball, J. Archaeol. Sci. 56 (2015) 233-241. 10.1016/j.jas.2015.02.021

[31] M. Shi, F. Zhou, Investigation on Glasses of the Han Dynasty Unearthed from Datong, Qinghai Province, Sci. Conserv. Archaeol. 2 (1990) 22-26.

[32] B. Siqin, Q. Li, F. Gan, Investigation of ancient chinese potash glass by laser ablation inductively coupled plasma atomic emission spectroscopy, Spectrosc. Lett. 47 (2014) 427-438.

[33] H. Tait, 5000 years of glass, British Museum Press, London, 2011.

[34] T. Takaishi, J. Jin, T. Uchino, T. Yoko, Structural Study of PbO-B2O3 Glasses by Xray Diffraction and 11B MAS NMR Techniques, J. Am. Ceram. Soc. 83 (2000) $2543-2548$.

[35] N.A. Toropov, V.P. Barzakovskii, V.V. Lapin, N.N. Kurtseva, A.I. Boikova, Phase Diagrams of Silicate Systems: Handbook, 1974 Third Issue; Ternary Systems. Army Foreign Science and Technology Center Charlottesville Va.

[36] Jie Wang, M. Li, Q. Ma, Z. Zhang, M. Zhang, Julin Wang, Weathering of an Octagonal Pb0-Ba0-Si02 Glass Stick from the Warring States Period, Glass Enamel 42 (2014) 6-13.

[37] Y. Wang, Y. Zhou, Z. Yang, J. Cui, A technological combination of lead-glaze and calcium-glaze recently found in China: Scientific comparative analysis of glazed ceramics from Shangyu, Zhejiang Province, Plos One 14 (2019) e0219608.

[38] K.H. Wedepohl, K. Simon, The chemical composition of medieval wood ash glass from Central Europe, Chem. Erde - Geochem. 70 (2010) 89-97. 10.1016/j.chemer. 2009.12.006

[39] R. Wen, Z. Zhao, J. Ma, J. Wang, Chemical Analysis of Ancient Glass Beads from Shirenzigou Sites in Balikun County, Xinjiang, Spectrosc. Spectr. Anal 36 (2016) 2961-2965.

[40] N. Wood, Chinese Glazes: their origins, chemistry, and recreation, University of Pennsylvania Press, 1999.

[41] Y. Xia, Q. Ma, Z. Zhang, Z. Liu, J. Feng, A. Shao, W. Wang, Q. Fu, Development of Chinese barium copper silicate pigments during the Qin Empire based on Raman and polarized light microscopy studies, J. Archaeol. Sci. 49 (2014) 500-509.

[42] X. Yin, T.J. Huang, H. Gong, Chemical evolution of lead in ancient artifacts -A case study of early Chinese lead-silicate glaze, J. Eur. Ceram. Soc. 40 (2020) 2222-2228. 10.1016/j.jeurceramsoc.2020.01.002.

[43] F. Zhao, B. Chen, Y. Chai, J. Dong, Q. Li, pXRF Analysis of Serveal Glass Objects Unearthed from Xi'An and Discussion of relative issues, Archaeol. Cult. Relics (2015) 111-119. 